\title{
Skupnost $v$ težavah? Vpliv gentrifikacije na sosesko Bo-Kaap v Cape Townu
}

Bo-Kaap je stara delavska soseska v središču Cape Towna v Južnoafriški republiki. Leta 1930 je bila to prenaseljena in zanemarjena soseska s propadajočimi hišami. Leta 1941 so lokalne oblasti tam razlastile že približno 150 stanovanj zaradi programa celostne prenove tega območja, vendar je proces ustavila skupina za ohranitev malajske četrti, ki se je borila proti rušenju hišv v tej soseski. Danes je območje s slikovitimi hišami in z enajstimi mošejami del kulturne dediščine Cape Towna in pomembna turistična znamenitost. Kot v sosednji gentrificirani soseski De
Waterkant je bilo tudi tukaj veliko stanovanj prenovljeno in izboljšano. Cene nepremičnin so skokovito narastle, čeprav so še vedno razmeroma nizke. Število prodanih nepremičnin tako močno narašča, da se lokalne oblasti in predvsem muslimanski prebivalci nenehno borijo za ohranitev kulturne identitete soseske.

Ključne besede: gentrifikacija, identiteta, Cape Town, cene nepremičnin, ohranitev, skupnost 


\section{Uvod}

Bo-Kaap je ena najstarejših sosesk v Cape Townu in nahaja se zraven poslovnega središča. Nastala je konec 18. stoletja, ko so bila na tem območju zgrajena skromna stanovanja. Tedaj je namreč zaradi osvoboditve sužnjev in obsežnega priseljevanja iz Evrope primanjkovalo stanovanj za delavski razred. Že na začetku 20. stoletja je bila soseska Bo-Kaap degradirana in je spominjala na slum. Leta 1946 je skupina prostovoljcev in članov mestnega sveta poskušala preprečiti propadanje in izbrali so sedemnajst hiš, primernih za obnovo. Čeprav je bil proces urbane prenove na tem območju institucionaliziran in je temeljil na urbanistični politiki, je obenem postavil temelje za gentrifikacijo te soseske, kar lahko vidimo tudi v spremembah stanovanjskega fonda in prebivalcev. Ta proces se je v Cape Townu v ožjem obsegu začel kazati, še preden je Ruth Glass (1964) v začetku 60. let 20. stoletja, ko je londonske delavske četrti začel preplavljati višji in nižji srednji razred, skovala pojem »gentrifikacija «. Po preteku najemnega razmerja je zanemarjene in skromne kolibe prevzel višji sloj in jih spremenil v elegantna in draga stanovanja.

Konec 80. let 20. stoletja je gentrifikacija postala očitna v mestih po vsem svetu, zato je bila osrednji predmet številnih urbanističnih raziskav in razprav (Franzén, 2005). V preteklosti so gentrifikacijo razlagali predvsem kot $\gg$ vdor pripadnikov srednjega razreda z višjimi dohodki v delavske soseske v središču mesta, kar povzroči razselitev velikega števila prvotnih stanovalcev «. Gentrifikacija vključuje obnovo propadajočega stanovanjskega fonda, kar zadovolji potrebe novih lastnikov (Kotze in Van der Merwe, 2000, glej tudi Smith in Williams, 1986, in Bourne, 1993). Ker ta proces zviša najemnine, se morajo prvotni stanovalci, ki imajo nizke prihodke ali so celo brezposelni, sčasoma odseliti, nadomestijo pa jih pripadniki srednjega razreda. Da bi se zadovoljila pričakovanja prebivalcev z višjimi dohodki, se lahko spremenijo družbeni značaj in stroški storitev (Beauregard, 1986; Hamnett, 1991; Cameron, 1992, in Atkinson, 2000). Izkazalo pa se je, da se pojem nanaša na veliko bolj zapleten urbani proces, ki ga je težko razložiti. Gentrifikacija je sprožila nekaj gorečih razprav, v katerih nekateri raziskovalci podpirajo izvorno opredelitev Ruth Glass, vse več pa jih podpira širše razumevanje procesa (Lees idr., 2008, ter Visser in Kotze, 2008). »Zgodnji poskusi analize procesa so pogosto poudarjali vlogo posameznih nosilcev gentrifikacije in gradbenih investitorjev, le malo pozornosti pa so posvečali vlogi države.« (Murphy, 2008: 2522.)

Zakaj se je gentrifikacija razširila in zakaj jo v splošnem bolje razumemo, lahko pojasnimo na podlagi treh medsebojno povezanih procesov. Pri prvem se gentrifikacija razlaga kot ustvarjanje prefinjenega življenjskega sloga, ki je značilen za globalni kapitalistični razred (Rofe, 2003). Pri drugem procesu se je gentrifikacija zaradi novih globalnih vplivov razširila na nova območja. Rowland Atkinson in Gary Bridge (2005) navajata, da se je gentrifikacija iz velikih mest Severne Amerike, Zahodne Evrope in Avstralije očitno premaknila na druga območja po svetu. Tretjič, »gentrifikacija se razume kot pomemben del neoliberalizma « (Harris, 2008: 2409). Kot navaja Neil Smith (2002: 440), je gentrifikacija »do 90. let 20. stoletja postala pomemben urbani pristop, ki ga oblasti v mestih po vsem svetu uporabljajo v mestnem načrtovanju v sodelovanju z zasebnim kapitalom «. Pri razlagah globalne širitve gentrifikacije in samega trenda se proces obravnava v okviru svetovljanstva ali neoliberalizma (Harris, 2008). Andrew Harris (2008: 2409) je prepričan, da je to »deloma produkt raziskovalcev tega področja, ki ne zmorejo opravljati dela zunaj svoje podvede«. S tem se strinjata tudi Tim Butler in Loretta Lees (2006), ki trdita, da je v literaturi o globalizaciji in gentrifikaciji premalo pozornosti posvečeno izsledkom drugih področij.

Darren Smith (2008) navaja, da obstaja zanimanje za povezavo med gentrifikacijo in urbanistično politiko, ki se navadno osredotoča na dva sklopa raziskovalnih vprašanj. Prvi se osredotoča na politike, da bi poglobili znanje o izvoru in vzrokih gentrifikacije. Poudarek je na razjasnitvi povezave med časovno razsežnostjo gentrifikacije in nasprotujočimi si politikami upravljanja mest, pozornost pa je usmerjena na krepitev gospodarskega prestrukturiranja urbane pokrajine in stanovanjskega trga ter ponovno oblikovanje novega družbenega razreda na teh območjih (Smith, 1979, in Ley, 1994). Stuart Cameron (2003) meni, da raziskovalci preučujejo tudi stroške in koristi gentrifikacije, pri čemer želijo določiti posamezne skupine, ki imajo korist od procesa gentrifikacije oziroma zaradi njega trpijo. Rowland Atkinson (2004: 107) se sprašuje: »Ali gentrifikacija pomaga ali škodi stanovanjskim soseskam? « Vendar je »treba rahločutno upoštevati, da so različni vplivi gentrifikacije med seboj povezani in ukoreninjeni znotraj gentrificiranih območij ter da to vpliva na kakovost življenja in blaginjo različnih družbenih skupin tako z materialnega kot nematerialnega vidika « (Smith, 2008: 2543).

Medtem ko strokovnjaki razpravljajo o tem, ali gentrifikacija vodi v razselitev delavskega razreda ter segregacijo in družbeno polarizacijo $\mathrm{v}$ mestih, ta proces vse bolj podpirajo oblikovalci politik, ki so prepričani, da omogoča oblikovanje bolj trajnostnih mestnih skupnosti, ki so bolj socialno raznolike, manj segregirane in prispevajo $\mathrm{k}$ sprejemljivejšim bivalnim razmeram (Lees, 2008). Kot navaja Nicolas Blomley (2004), programi prenove pogosto podpirajo lastništvo stanovanj; to naj bi spodbujalo neodvisnost, podjetništvo in lokalni ponos. $S$ tega vidika je treba gentrifikacijo spodbujati, saj stanovalce, ki niso lastniki stanovanj, v njih živijo le začasno in so problematični, zamenja z dejavnimi in odgovornimi lastniki, ki želijo sosesko izboljšati. 
Avtor v članku preučuje stanovanjske spremembe v predmestni soseski Bo-Kaap in ugotavlja njihov vpliv na prebivalce. Odkriva spremembe ter analizira različne vplive v zgodovinski soseski v Cape Townu, ki so pomagali spremeniti nekdanji slum v eno najbolj priljubljenih sosesk v mestu. Podrobna analiza poslovnega središča in okoliških sosesk v Cape Townu je pokazala, da je imela gentrifikacija pomembno vlogo pri prenovi mestnega središča, še posebej na preučevanem območju. Namen članka ni dokazati, da v soseski Bo-Kaap poteka gentrifikacija, ampak predstaviti njene prebivalce in njihovo zgodovino, pri čemer avtor analizira vpliv političnih procesov in spreminjajočega se okolja na kulturno in družbeno tkivo preučevanega območja. Raziskava se od drugih razlikuje $\mathrm{v}$ tem, da preučuje zgodovinski razvoj izbranega območja in vpliv gentrifikacije (to je izboljšsanje stanovanj in posledične višje cene nepremičnin) na družbeno tkivo prebivalstva, ki se lahko izraža v razselitvi tradicionalnih prebivalcev soseske.

Podatki o družbeno-gospodarskih lastnostih prebivalcev soseske Bo-Kaap so bili pridobljeni iz popisov prebivalstva, opravljenih v letih 1996, 2001 in 2011. Avtor je podatke dobil tudi iz arhiva mestne občine Cape Town, in sicer o številu in velikosti prodanih nepremičnin, prodajnih cenah in naslovih na preučevanem območju ali zunaj njega, na katere so se pošiljali prvotni občinski računi. Dodaten vir informacij je bil tudi urad zemljiške knjige v Cape Townu, ki hrani listine o lastništvu, ki dokazujejo lastništvo in bremena na vseh nepremičninah. $\mathrm{Na}$ podlagi podatkov, pridobljenih $\mathrm{z}$ občine in iz zemljiške knjige, je avtor ugotovil, ali se na območje priseljujejo novi prebivalci. Da bi ocenil odnos do sprememb v soseski, je na lokalni tržni dan opravil intervjuje s posamezniki, ki so bili pripravljeni z njim govoriti, ter tudi $s$ predstavniki lokalnih oblasti in z verskimi voditelji.

Članek je razdeljen na pet delov. V prvem delu avtor na kratko opiše razvoj in ohranitev obravnavane zgodovinske soseske, $\mathrm{v}$ drugem pa preučuje razvoj rasne identitete, ki je na območju veljala v času apartheida. V tretjem poglavju predstavi današnje stanovalce in mestno identiteto prebivalcev soseske Bo-Kaap. $\mathrm{V}$ četrtem delu obravnava trenutne vidike nepremičninskega trga na tem območju, nato pa članek konča s sklepnimi ugotovitvami.

\section{Razvoj in ohranitev soseske Bo-Kaap}

Stanovanjska soseska Bo-Kaap na obrobju poslovnega središča Cape Towna je nastala v zadnjih dveh desetletjih 18. stoletja in se nato 150 let razvijala (Todeshini in Japha, 2003). $\mathrm{Na}$ načrtu Cape Towna, ki so ga leta 1786 izdelali Van der Graaf, Barbier in Tribault, je jasno vidna načrtovana gradnja

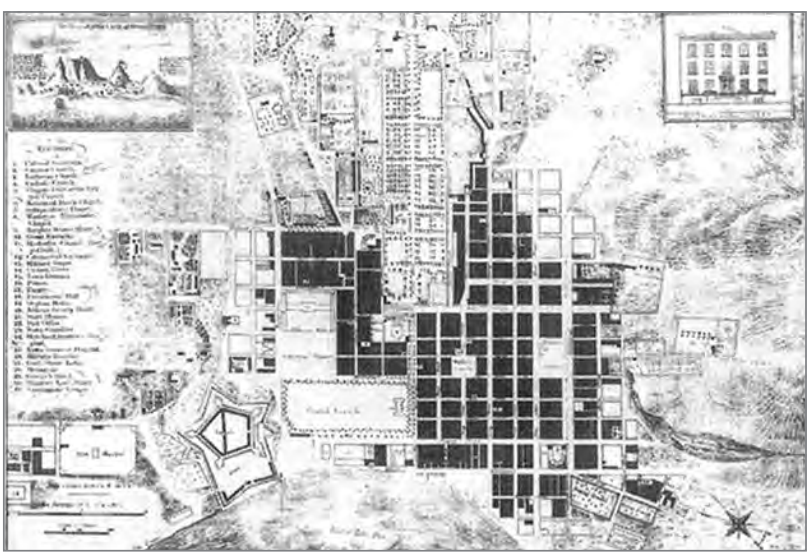

Slika 1: Thompsonov načrt Cape Towna iz leta 1827. Na desni so že vidne ulice v soseski Bo-Kaap (vir: Todesini in Japha, 2003).

ulic v mestu vse do ulice Buitengracht, na območju današnje soseske Bo-Kaap pa ni sledu o kakršni koli gradnji. Gradnja vzporednih ulic Rose in Chippinni je bila prvič predvidena na Thompsonovem načrtu iz leta 1827 (slika 1), na Snowovem načrtu iz leta 1862 pa je že razvidna ulična razporeditev na območju soseske Bo-Kaap. Prostorsko načrtovanje območja je bilo odziv na vse večje priseljevanje, osvoboditev sužnjev in veliko povpraševanje po stanovanjih z ugodnimi najemninami za rastoče prebivalstvo (Wilkinson in Kragolsen-Kille, 2006).

Do 30. let 20. stoletja je Bo-Kaap postala prenaseljena in degradirana soseska v bližini mestnega poslovnega središča. Tedaj so se v lokalnem časopisju nenehno pojavljale pritožbe glede slumov, zlasti na območjih Jerry Street Ward, District Six in Bo-Kaap v ožjem središču mesta. Leta 1934 je vlada sprejela zakon o slumih, ki je uvedel mehanizem vključevanja lokalnih oblasti v mestnih slumih. Lokalne oblasti so dobile široka pooblastila za poseganje na območja slumov v svoji pristojnosti (Todesini in Japha, 2003). Do leta 1941 so lokalne oblasti na območju soseske Bo-Kaap za obsežen program prenove razlastile približno 150 hiš, večinoma zgrajenih v 18. in 19. stoletju (Wilkinson in Kragolsen-Kille, 2006).

Leta 1943 je bilo rušenje soseske Bo-Kaap skoraj neizogibno, vendar je proces ustavila skupina za ohranitev malajske četrti, ki jo je vodil E. Jansen. V njej so bili tudi akademik in pisatelj I. D. du Plessis in drugi ugledni prebivalci Cape Towna, ki jim je uspelo preprečiti vsakršno rušenje $\mathrm{v}$ tej soseski (Todesini in Japha, 2003). Člani skupine so se zavzemali za vključitev komisije za zgodovinske spomenike (ang. Historical Monuments Commission, v nadaljevanju: HMC), ki je takoj podprla ohranitev »stare malajske arhitekture « (arhiv mestne občine Cape Town, 3/CT 4/2/1/1/720). Leta 1946 sta skupina in mestna občina Cape Town določili 17 hiš za ohranitev in obnovo. Na sliki 2 je prikazano značilno ulično dogajanje, na desni strani ulice pa je vidna ena od mošej. Projekt se je končal leta 1950, vendar so stroški presegli predvideni proračun. To je vodilo 


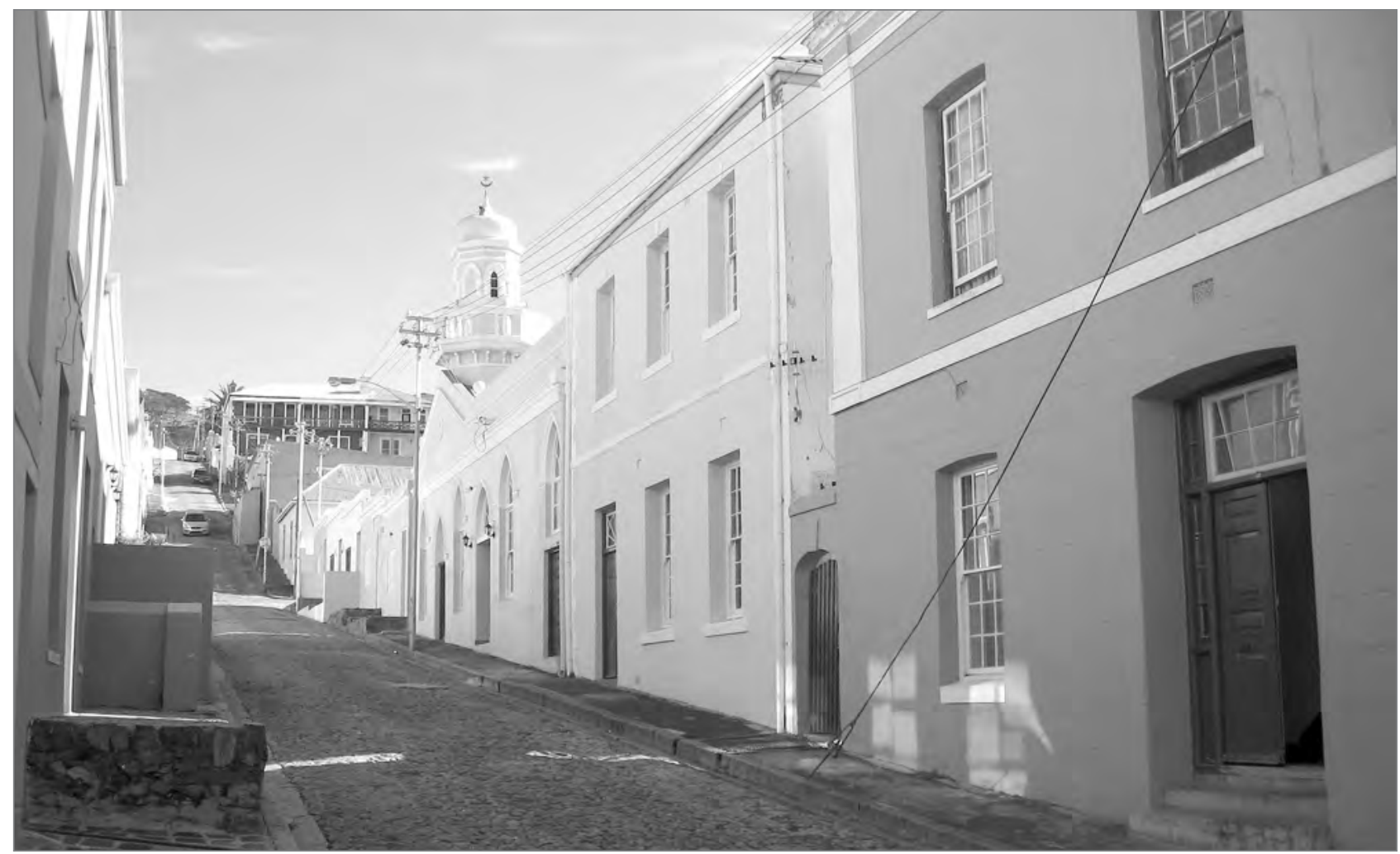

Slika 2: Prizor iz soseske Bo-Kaap; dobro je vidna ena od enajstih mošej (foto: Nico Kotze).

$\mathrm{v}$ desetletje napetosti. Mestni svet je hotel obnoviti območje, vendar je bilo ravnovesje moči tako, da nobena stran ni mogla doseči svojega; svet namreč ni mogel prenoviti območja brez sodelovanja HMC (Todesini in Japha, 2003).

Prihod na oblast nacionalne stranke leta 1948 je bil zelo pomemben za ohranitev soseske Bo-Kaap. Stranka je poudarjala etnično pripadnost in v Južnoafriški republiki sprožila razvoj politično segregiranih mest v okviru apartheida. Leta 1951 je bil du Plessis imenovan za komisarja za zadeve prebivalstva mešane rase. To je bil zavidljiv položaj, s katerega je lahko uveljavljal svoje stališč glede malajskega vprašanja in to območje razglasil za »območje malajske rasne skupine « (Wilkinson in Kragolsen-Kille, 2006). Ta mejnik je bil dosežen leta 1957 in od leta 1962 so lahko na območju soseske Bo-Kaap nepremičnine posedovali samo izbrani Malajci (Todesini in Japha, 2003). Leta 1961 je bil ustanovljen oddelek za razvoj skupnosti, ki naj bi usklajeval izvajanje zakona o območjih, rezerviranih za določeno rasno skupino (ang. Group Areas Act). Vodenje tega oddelka in oddelka za zadeve prebivalstva mešane rase je prevzel P. W. Botha, du Plessis pa je napredoval na mesto glavnega sekretarja. Eden prvih du Plessisovih ukrepov je bil predlog, naj se vse območje soseske Bo-Kaap razglasi za državni spomenik. V tem času so se odločili ohraniti pročelja hiš na tem območju, za njimi pa so zgradili sodobnejše stavbe (Todesini in Japha, 2003).

\section{3 "Pomalajčevanje« skupnosti v soseski Bo-Kaap}

Robyn Wilkinson in Astrid Kragolsen-Kille (2006) trdita, da izraz »Malajec « v južnoafriškem kontekstu izvira iz suženjstva in nima etničnega pomena. Samo približno en odstotek od 63.000 sužnjev, ki so bili pripeljani v Kaplandijo, je prihajal iz Malezije; večina jih je prihajala iz Indije, Afrike, Madagaskarja in Jugovzhodne Azije. Poleg tega je bilo v letih, ko je Cape Town šele nastajal, prebivalstvo zelo raznoliko, sporazumevali pa so se predvsem v malajščini ter mešanici malajščine in portugalščine, v katerih je potekala trgovina na območju Indijskega oceana. Po letu 1770 je ta jezika zamenjala nizozemščina, ki se je postopoma razvila v afrikanščino (Davids, 1990).

Razvoj »malajske « identitete se je nadaljeval, ko so delavci z otokov Maluku in politični zaporniki iz Indonezije v Kaplandijo prinesli islam. Vera se je tam zares prijela šele $\mathrm{v}$ začetku 19. stoletja, ko so bili v kaplandsko kolonijo pripeljani muslimanski sužnji iz Bengalije, $\mathrm{z}$ Malabarske obale in iz notranjosti Indije. Izraz »Malajec « se je v 19. stoletju uporabljal za nebele muslimanske prebivalce (Todesini in Japha, 2003). Pogosteje se je začel uporabljati v prvi polovici 20. stoletja, zlasti v obdobju apartheida, ko je veliko muslimanskih govorcev afrikanščine prevzelo to ime v upanju, da jih bo belska elita sprejela. Vsakršna povezava s črnci je namreč $\mathrm{v}$ kontekstu zatiranja in rasizma v državi pomenila težave (Jeppe, 1986). 
Preglednica 1: Spremembe prebivalstva v soseski Bo-Kapp po podatkih popisov prebivalstva, opravljenih v letih 1996, 2001 in 2011

\begin{tabular}{|c|c|c|c|}
\hline Spremenljivke & $1996(\%)$ & $2001(\%)$ & $2011(\%)$ \\
\hline \multicolumn{4}{|l|}{ Narodnost } \\
\hline mešanci & 79,0 & 73,1 & 95,2 \\
\hline belci & 2,7 & 6,6 & 0,3 \\
\hline Indijci & 3,8 & 6,1 & 3,2 \\
\hline črnci & 2,6 & 14,1 & 1,3 \\
\hline neopredeljeni & 11,9 & & \\
\hline \multicolumn{4}{|l|}{ Vera } \\
\hline islam & & & 56,9 \\
\hline krščanstvo & & & 4,9 \\
\hline drugo & & & 38,2 \\
\hline \multicolumn{4}{|l|}{ Starost } \\
\hline$\leq 17$ let & * & 28,4 & 33,3 \\
\hline 18-54 let & * & 53,8 & 49,9 \\
\hline$>55$ let & 15,3 & 17,7 & 16,7 \\
\hline \multicolumn{4}{|l|}{ Jezik } \\
\hline angleščina & 72,4 & 75,3 & 58,5 \\
\hline afrikanščina & 25,0 & 22,6 & 38,7 \\
\hline angleščina/afrikanščina & & & 1,9 \\
\hline afriški jeziki/drugo & 1,6 & 2,1 & 0,9 \\
\hline \multicolumn{4}{|c|}{ Izobrazba starejših od 15 let } \\
\hline do 11. razreda & 62,6 & 52,2 & \\
\hline 12 razredov & 21,9 & 25,3 & \\
\hline višja šola ali univerza & 15,4 & 22,6 & \\
\hline \multicolumn{4}{|l|}{ Zaposlitveni status } \\
\hline zaposleni & 50,9 & 50,6 & \\
\hline brezposelni & 49,1 & 49,4 & \\
\hline
\end{tabular}

Opomba: $\left(^{*}\right)$ starostne skupine se niso ujemale Vir: južnoafriški statistični urad (1996, 2001 in 2011)

Kot piše Achmat Davids (1990), je bila Bo-Kaap vse do konca 20. let 20. stoletja rasno mešana soseska, v kateri so živeli revni prebivalci. Številne mošeje so na tem območju zgradili lokalni muslimanski prebivalci, ki so se z naraščanjem števila muslimanov začeli deliti na različne skupine. Anketa iz leta 1946 jasno kaže raznolikost prebivalstva: $40 \%$ prebivalcev je bilo $\gg$ Malajcev« (nebeli muslimani), 31 \% Afričanov, $27 \%$ mešancev (kristjanov) in $2 \%$ Indijcev (arhiv mestne občine Cape Town, 3/CT 4/2/1/1/720 20/6/46).

Ko se je začel du Plessis zavzemati za ohranitev malajske četrti (ang. Malay Quarter), za domnevne socialne težave v soseski Bo-Kaap ni krivil revščine, ampak prisotnost priseljencev (Afričanov; du Plessis in Lückoff, 1953). Za ohranitev soseske se ni zavzemal samo zato, da bi »ohranil malajsko arhitekturo, ampak tudi obnovil razredčeno malajsko skupnost $\mathrm{v}$ etnično čisti soseski « (Todesini in Japha, 2003: 197). Pri doseganju svojih ciljev je apartheidsko vlado opozoril na to, da bi bila selitev Malajcev iz malajske četrti v popolnem nasprotju s ci- ljem ohranjanja ponosa in zadovoljstva različnih rasnih skupin, predvidenim v zakonu o območjih, rezerviranih za določeno rasno skupino (Todesini in Japha, 2003). Po njegovi zaslugi se je soseska ohranila, medtem ko so druga območja, kot je bilo District Six, porušili do tal, prebivalce pa preselili v sosesko Mitchell's Plain in druge stanovanjske soseske za nebelce v Cape Townu.

\section{Današnja skupnost $v$ soseski Bo-Kaap}

Nico Kotze in Izak Van der Merwe (2000) sta preučevala, ali lahko urbano prenovo v Cape Townu obravnavamo kot proces gentrifikacije. $\mathrm{V}$ ta namen sta na podlagi diskriminantne analize oblikovala profil tipičnega nosilca gentrifikacije, vendar sta našla zelo malo dokazov, ki bi lahko potrdili, da povprečni prebivalec soseske Bo-Kaap ustreza povprečnemu gentrifikacijskemu profilu, ki je bil oblikovan za Cape Town.

Trenutno si manjša skupina lokalnega prebivalstva v soseski Bo-Kaap (aktivisti, lokalni vodje in verske skupine) prizadeva za ohranitev svoje »kaplandske malajske « (ang. Cape Malay) kulture. Podobno se na primer dogaja tudi v Santiágu, kjer se »družbene skupine zgoščajo na določenih območjih v mestu in ustvarjajo družbeno enovite soseske « (Márquez in Pérez, 2008, navedeno v Márquez, 2011: 88). Kot je razvidno iz popisov prebivalstva, opravljenih v letih 1996, 2001 in 2011, se poimenovanje »Cape Malay « za ločeno etnično skupino sploh ne uporablja več (preglednica 1). Zato se pojavlja vprašanje, ali je bilo to ime samo še ena oblika rasistične manipulacije apartheidske vlade v preteklosti. Očitno je, da danes to območje skoraj v celoti ( $95 \%$ ) poseljujejo mešanci (ang. Coloureds). Med popisom prebivalstva leta 1996 skoraj $12 \%$ prebivalcev ni navedlo svoje rase, vendar se je to pozneje spremenilo. $\mathrm{O}$ razlogih za to lahko samo ugibamo: morda so prebivalci želeli ohraniti svojo kaplandsko malajsko identiteto, morda pa je v današnjem političnem ustroju Južnoafriške republike bolj »modno « in ugodno biti mešanec. Kar je presenetljivo pri popisu iz leta 2011, je zmanjšanje števila pripadnikov drugih rasnih skupin v soseski Bo-Kaap.

V popisu prebivalstva iz leta 2011 se je večina prebivalcev izrekla za islam (glej preglednico 1). Starostna sestava prebivalstva na preučevanem območju se ni veliko spremenila, kar se razlikuje od drugih gentrificiranih območij po svetu (Fillion, 1991; Lees, 1994), na katera se priseljujejo mlajši ljudje. Preseneča pa sprememba v jeziku prebivalstva iz popisa leta 2011, ki kaže padec števila angleško govorečih in povečanje števila prebivalcev, ki govorijo afrikanščino. To je lahko posledica spreminjajočih se odnosov v Južnoafriški republiki in dejstva, da so ljudje bolj odprti in jih ni sram priznati, da govorijo afrikanščino, torej 
jezik, ki je tesno povezan z nacionalno stranko in apartheidsko dediščino države. $\mathrm{V}$ popisu iz leta 2011 pri izobrazbi in zaposlitvenem statusu žal niso bile uporabljene enake kategorije; primerjava popisov iz leta 1996 in 2001 razkriva, da je leta 2001 več prebivalcev imelo višjo izobrazbo, pri zaposlitvi pa je bilo prav obratno (glej preglednico 1). Prav tako lahko ugotovimo, da se družbeno-gospodarske značilnosti prebivalstva v soseski Bo-Kaap med letoma 1996 in 2001 niso veliko spremenile, kar se ujema z raziskavo, ki so jo opravili Ronnie Donaldson idr. (2013), ki so za preučevanje sprememb v prebivalstvu soseske uporabili enake spremenljivke in vprašalnik kot Nico Kotze (1998). To jasno kaže, da del stare opredelitve gentrifikacije, ki se nanaša na »zamenjavo « prebivalstva, za sosesko Bo-Kaap ne velja.

\section{Značilnosti nepremičninskega trga v soseski Bo-Kaap}

Podrobna analiza nepremičnin na preučevanem območju, potrjuje, da se je skozi čas veliko stvari spremenilo. Stanovanja so se izboljšala (glej sliki 3 in 4, na katerih ni sledu o slumu) in vrednost nepremičnin je skokovito narastla (preglednica 2). $\mathrm{Na}$ vrednost stanovanj vplivajo njihove lastnosti, kot so velikost, opremljenost, razporeditev prostorov, fizično stanje, dostopnost in okolica. Poleg tega izsledki drugih raziskav kažejo, da na vrednost stanovanja nedvomno vpliva soseska (Kain in Quigley, 1970; Boyle in Kiel, 2001; Din idr., 2001; Yau, 2011, ter Zhang idr., 2012). V preglednici 2 je jasno vidna rast vrednosti nepremičnin na tem območju v zadnjih 30 letih: povprečna cena s slabih 20.000 ZAR leta 1981 je narastla na več kot 1.000.000 ZAR (približno 120.000 EUR) leta 2011. Če natančneje preučimo povprečno ceno nepremičnin leta 1981, ugotovimo, da se je takrat novozgrajena hiša s tremi spalnicami in z dvema kopalnicama v severnem predmestju Cape Towna prodajala za 35.000 ZAR. Še vedno je razmeroma malo nepremičnin, ki so zamenjale lastnike, vendar pa njihovo število $\mathrm{v}$ zadnjem času narašča. $V$ preteklosti je bilo zelo malo nepremičnin oglaševano na nepremičninskem trgu, in sicer predvsem zato, ker so prebivalci namenoma želeli zaščititi muslimanski značaj območja. Novice o nepremičninah, ki so bile naprodaj, so raje širili ustno med prijatelji in sorodniki (Kotze, 1998).

Žal podatki mestne občine Cape Town ne vključujejo podatkov o velikosti hiš oziroma stanovanj na posamezni parceli; podani so samo podatki o velikosti parcele. Iz preglednice 2 je jasno razvidno, da so parcele z vidika celotne Južnoafriške republike zelo majhne. V premožnejših soseskah drugih južnoafriških mest so parcele velike od $1.000 \mathrm{~m}^{2}$ naprej in celo hiše, ki jih južnoafriška vlada namenja brezdomcem, se nahajajo na parcelah, velikih $250 \mathrm{~m}^{2}$ (glej Moolla idr., 2011). V soseski prevladujejo vrstne hiše in dvojčki; večina ima zelo majhne vrtove ali pa jih sploh nima.

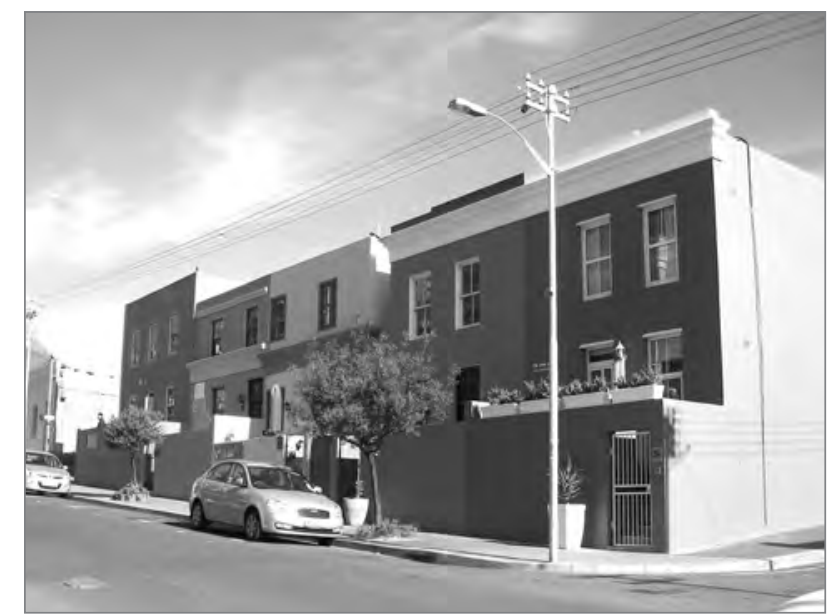

Slika 3: Obnovljene hiše v soseski Bo-Kaap s pročelji prvotnih hiš (foto: Nico Kotze)

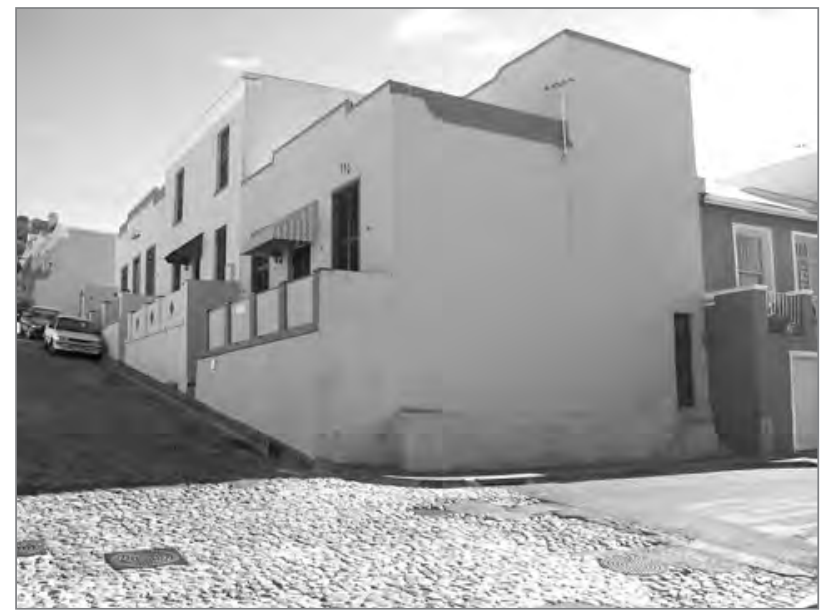

Slika 4: Najcenejša hiša, prodana v soseski Bo-Kaap leta 2011 (foto: Nico Kotze).

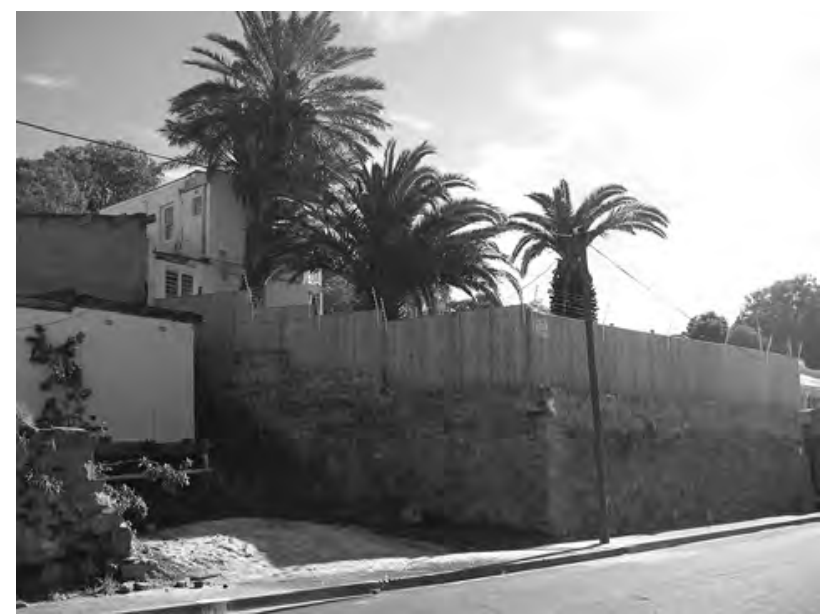

Slika 5: Najdražja prodana hiša v soseski Bo-Kaap leta 2011, ki jo je novi lastnik v celoti prenovil (foto: Nico Kotze).

Najmanjša prodana nepremičnina leta 2011 se je izkazala tudi za najcenejšo v tem letu (slika 4). Nepremičnina zavzema celotno parcelo, njena terasa pa sega vse do roba ceste. Hiša se nahaja na vogalu ulic Chippinni Street in Church in se na obeh straneh dotika drugih hiš, kar pomeni, da na teh dveh straneh 
Preglednica 2: Spremembe v prodaji in ceni nepremičnin (1981-2011)

\begin{tabular}{lllll}
\hline Značilnosti nepremičnine & 1981 & 1991 & 2001 & 2011 \\
\hline število prodanih stanovanj & 6 & 16 & 15 & 22 \\
\hline najnižja cena (ZAR) & 85.000 & 1.000 & 37.500 & 700.000 \\
\hline najvišja cena (ZAR) & 27.500 & 145.000 & 650.000 & 2.650 .000 \\
\hline povprečna cena prodanih nepremičnin (ZAR) & 19.667 & 46.181 & 282.633 & 1.292 .387 \\
\hline najmanjša prodana parcela $\left(m^{2}\right)$ & 109 & 48 & 69 & 61 \\
\hline največja prodana parcela $\left(m^{2}\right)$ & 342 & 376 & 627 & 527 \\
\hline povprečna velikost prodane parcele $\left(m^{2}\right)$ & 164 & 128 & 253 & 159 \\
\hline število najetih hipotek (samo za leto 2011) & & & & 7.278 \\
\hline najnižja vrednost hipoteke v ZAR (samo za leto 2011) & & & & 900.00 \\
\hline najvišja vrednost hipoteke v ZAR (samo za leto 2011) & & & $213.880^{* *}$ \\
\hline povprečna vrednost hipoteke v ZAR (samo za leto 2011) & & & \\
\hline
\end{tabular}

Opomba: $\left(^{*}\right)$ Imetnik hipoteke je eden od prejšnjih lastnikov; $\left.{ }^{* *}\right)$ povprečje je izračunano samo za šest nepremičnin (višina ene hipoteke ni bila podana).

Vir: prirejeno po R. Donaldsonu idr. (2013)

hiše ni oken. Na pročelju ima samo vrata in dve okni. Najdražja prodana nepremičnina leta 2011 se nahaja na največji parceli. Med letoma 2011 in 2012 je novi lastnik to dvonadstropno stavbo v celoti prenovil (glej sliko 5). Druga dobra lastnost te stavbe je, da se nahaja na vrhu hriba $\mathrm{z}$ lepim razgledom na Mizasto goro (ang. Table Mountain), pristanišče in poslovno središče Cape Towna.

Pogovori s prebivalci soseske Bo-Kaap so razkrili, da v mnogih hišah živita dve generaciji ali celo tri. Težko pa je ugotoviti, ali je skupnost $\mathrm{v}$ težavah zaradi gentrifikacije soseske. Vrednost nepremičnin se je $\mathrm{v}$ tem predmestju močno povečala, zaradi česar si jih nekateri prebivalci ne morejo privoščiti. Če natančno pogledamo podatke urada zemljiške knjige v Cape Townu o uporabi in dodelitvi hipotek za financiranje 22 nepremičnin, prodanih leta 2011, lahko ugotovimo, da je samo sedem (31,8 \%) novih lastnikov najelo hipoteko. Ena od listin o lastništvu ne vsebuje podatka o vrednosti hipoteke, po podatkih zemljiške knjige pa naj bi bil imetnik hipoteke prejšnji lastnik, in sicer ženska, ki je nepremičnino kupila leta 1991. Tako sta mogoča dva scenarija: ženska se je poročila in nepremičnino je prevzel njen mož ali pa jo je prenesla na brata oziroma sestro. Slednje je manj verjetno, ker ima novi lastnik drugačen priimek.

Če povprečno ceno nepremičnin (1.292.387 ZAR) primerjamo s povprečno višino hipoteke (213.880 ZAR) leta 2011 oziroma upoštevamo, da nekatere nepremičnine niso imele hipoteke, se zdi, da prebivalci soseske Bo-Kaap s stališča lastništva stanovanj v resnici sploh niso tako revni. Kar bi lahko za lastnike v prihodnje postalo problem, je to, da bi vsi bratje in sestre zahtevali zakoniti delež vrednosti, ki bi jo nepremičnina lahko dosegla na trgu. To bi lahko vodilo v prodajo stanovanj priseljencem in celo tujcem, ki plačo služijo v evrih.

\section{Sklep}

Po letu 2000 se je propadanje ožjega središča Cape Towna začelo močno ustavljati, medtem ko ta smer razvoja v drugih večjih mestih v Južnoafrǐši republiki ni tako opazna. V Cape Townu se propadanje preprečuje s programi prenove, kot je obnova mestnega središča (ang. City-Centre Improvement District), in z obsežnimi naložbami v infrastrukturo, kot so promet, konferenčna središča, novi hoteli, preoblikovanje prostorov v pisarne in gradnja na območju Victoria \& Albert Waterfront in tamkajšnje marine, ki so jasno obrnili trend propadanja mesta. Preobrat je omogočil razvojni okvir državne vlade in lokalnih uprav, ki so imele pomembno vlogo pri obnovi poslovnega središča Cape Towna (glej Visser in Kotze, 2008). Ta razvoj je vplival tudi na sosesko Bo-Kaap, saj so bile stare industrijske stavbe v tej soseski predelane v stanovanja, zgradili pa so celo nov hotel Hilton, ki je bil za nekatere prebivalce velik kamen spotike.

Žal ta plat zgodbe ne potrjuje zamisli o razselitvi prebivalcev, ki je značilna za tradicionalno razumevanje gentrifikacije. Zgodba jasno kaže, da je v soseski Bo-Kaap v več desetletjih prišlo do ogromnih sprememb. Iz propadajoče soseske s stavbami, ki so bile v 30. letih 20. stoletja tik pred rušenjem, se je spremenila $\mathrm{v}$ trendovsko in zaželeno območje, ki privlači obiskovalce Cape Towna (prvo naselbinsko območje v Južnoafriški republiki). Vse te spremembe so verjetno slabo vplivale na starejše prebivalce, ki tam še vedno živijo in bi radi na vsak način ohranili stari »kaplandski malajski muslimanski « značaj soseske Bo-Kaap. Avtor meni, da bo z nadaljnjim naraščanjem cen nepremičnin in izumrtjem stare generacije vse več stanovanj prišlo v roke priseljencev in ta očarljiva soseska bo izgubila svoje izrazite značilnosti. Kljub temu je to samo domneva, in ko človek posluša prebivalce govoriti o svojih strahovih in odnosih, dobi 
močan občutek, da bodo naredili vse, kar je v njihovi moči, da bi svojo sosesko in kulturno dediščino ohranili nedotaknjeni.

\section{Nico Kotze}

University of Johannesburg, Department of Geography, Environmental Management and Energy Studies, Johannesburg, Južnoafriška republika

E-pošta: nicok@uj.ac.za

\section{Viri in literatura}

Arhiv mestne občine Cape Town, mapa 3/CT 4/2/1/1/720. Cape Town. Arhiv mestne občine Cape Town, mapa 3/CT 4/2/1/1/720 20/6/46. Cape Town.

Atkinson, R. (2000): The hidden cost of gentrification: Displacement in central London. Journal of Housing and the Built Environment, 15(4), str. 307-326. DOI: 10.1177/0042098008097104

Atkinson, R. (2004): The evidence of the impact of gentrification: New lessons for the urban renaissance? European Journal of Housing Policy, 4(1), str. 107-131. DOI: 10.1080/1461671042000215479

Atkinson, R., in Bridge, G. (ur.) (2005): Gentrification in a global context: The new urban colonialism. London, Routledge. DOI: $10.4324 / 9780203392089$

Beauregard, R. A. (1986): The chaos and complexity of gentrification. V: Smith, N., in Williams, P. (ur.): Gentrification of the city. Boston, Allen \& Unwin.

Blomley, N. (2004): Unsettling the city: Urban land and the politics of property. New York, Routledge.

Bourne, L. S. (1993): The demise of gentrification? A commentary and prospective view. Urban Geography, 14(1), str. 95-107. DOI: 10.2747/0272-3638.14.1.95

Boyle, M. A., in Kiel, K. A. (2001): A survey of house price hedonic studies of the impact of environmental externalities. Journal of Real Estate Literature, 9(2), str. 117-144.

Butler, T., in Lees, L. (2006): Super-gentrification in Barnsbury, London: Globalization and gentrifying global elites at the neighbourhood level. Transactions of the Institute of British Geographers, 31(4), str. 1-21. DOI: $10.1111 /$ j.1475-5661.2006.00220.x

Cameron, S. (1992): Housing, gentrification and urban regeneration policies. Urban Studies, 29(1), str. 3-14. DOI: 10.1080/00420989220080011

Cameron, S. (2003): Gentrification, housing redifferentiation and urban regeneration: 'Going for growth' in Newcastle-upon-Tyne. Urban Studies, 40(12), str. 2367-2382. DOI: 10.1080/0042098032000136110

Davids, A. (1990): Words the Cape slaves made: A socio-historical-linguistic study. South African Journal of Linguistics, 8(1), str. 1-24. DOI: $10.1080 / 10118063.1990 .9723811$

Din, A., Hoesli, M., in Bender, A. (2001): Environmental variables and real estate prices. Urban Studies, 38(11), str. 1989-2000. DOI: $10.1080 / 00420980120080899$

Donaldson, R., Kotze, N., Visser, G., Park, J. Wally, N., Zen, J., in Vieyra, O. (2013): An uneasy match: Neoliberalism, gentrification and heritage conservation in Bo-Kaap, Cape Town, South Africa. Urban Forum, 24(2), str.173-188. DOI: 10.1007/s12132-012-9182-9

Du Plessis, I. D., in Lückoff, C. (1953): The Malay Quarter and its people. Cape Town, Balkema.

Fillion, P. (1991): The gentrification - social structure dialectic: A Toronto case study. International Journal of Urban and Regional Research, 15(4), str. 553-574. DOI: 10.1111/j.1468-2427.1991.tb00658.x

Franzén, M. (2005): New social movements and gentrification in Hamburg and Stockholm: A comparative study. Journal of Housing and the Built Environment, 20(1), str. 51-77. DOI: 10.1007/s10901-005-6764-z

Glass, R. (1964): London: Aspects of change. London, MacGibbon \& Kee. Hamnett, C. (1991): The blind men and the elephant: The explanation of gentrification. Transactions, Institute of British Geographers, 16(2), str. 173-189. DOI: $10.2307 / 622612$

Harris, A. (2008): From London to Mumbai and back again: Gentrification and public policy in comparative perspective. Urban Studies. 45(12), str. 2407-2428. DOI: 10.1177/0042098008097100

Jeppe, S. (1986): Historical process and the constitution of subjects. Cape Town, University of Cape Town.

Južnoafriški statistični urad (1996): 1996 census. Pretoria.

Južnoafriški statistični urad (2001): 2001 census. Pretoria.

Južnoafriški statistični urad (2011): 2011 census. Pretoria.

Kain, J. F., in Quigley, J. M. (1970): Measuring the value of housing quality. Journal of the American Statistical Association, 65(330), str. 532-548. DOI: $10.2307 / 3384565$

Kotze, N. (1998): Gentrifikasie as Stedelik Geografiese verskynsel in Kaapstad [Gentrification as an urban geographical phenomenon in Cape Town]. Doktorska disertacija. Stellenbosch, University of Stellenbosch.

Kotze, N., in Van der Merwe, I. J. (2000): Neighbourhood renewal in Cape Town's inner city: Is it gentrification? Journal of Family Ecology and Consumer Sciences, 28, str. 39-46.

Lees, L. (1994): Gentrification in London and New York: An Atlantic gap? Housing Studies, 9(2), str. 199-217. DOI: 10.1080/02673039408720783

Lees, L. (2008): Gentrification and social mixing: Towards an inclusive urban renaissance. Urban Studies, 45(12), str. 2449-2470. DOI: $10.1177 / 0042098008097099$

Lees, L., Slater, T., in Wyly, E., (2008): Gentrification. New York, Routledge. Ley, D. (1994): Gentrification and the politics of the new middle class. Environment and Planning D, 12(1), str. 53-74. DOI: 10.1068/d120053

Márquez, F. (2011): Santiago: Modernisation, segregation and urban identities in the twenty-first century. Urbani izziv, 22(2), str. 14-24. DOI: 10.5379/urban-izziv-2011-22-02-002

Moolla, R., Kotze, N., in Block, L. (2011): Housing satisfaction and quality of life in RDP houses in Braamfischerville, Soweto: A South African case study. Urbani izziv, 22(1), str. 60-65.

DOI: 10.5379/urbani-izziv-2011-22-01-005

Murphy, L. (2008): Third-wave gentrification in New Zealand: The case of Auckland. Urban Studies, 45(12), str. 2521-2540. DOI: 10.1177/0042098008097106

Rofe, M. W. (2003): 'I want to be global': Theorising the gentrifying class as an emergent elite global community. Urban Studies, 40(12), str. 2511-2526. DOI: 10.1080/0042098032000136183

Smith, D. (2008): The politics of studentification and '(un)balance' urban populations: Lessons for gentrification and sustainable communities? Urban Studies, 45(12), str. 2541-2564. DOI: 10.1177/0042098008097108

Smith, N. (1979): Towards a theory of gentrification: A back-to-the-city movement of capital, not people. Journal of the American Planning Association, 45(4), str. 583-548. DOI: 10.1080/01944367908977002

Smith, N. (2002): New globalism, new urbanism: gentrification as a global urban strategy. Atipode, 34(3), str. 427-450. DOI: $10.1111 / 1467-8330.00249$ 
Smith, N., in Williams, P. (ur.) (1986): Gentrification of the city, London, Unwin Hyman.

Todeschini, F., in Japha, D. (2003): Cultural identity and architectural image in Bo-Kaap. V: AlSayyad, N. (ur.): The end of tradition?, str. 187208. London, Routledge.

Visser, G., in Kotze, N. (2008): The state and new-built gentrification in central Cape Town. Urban Studies, 45(12), str. 2565-2593. DOI: $10.1177 / 0042098008097104$

Wilkinson, R., in Kragolsen-Kille, A. (2006): Bo-Kaap: Inside Cape Town's Malay quarter. Cape Town, Struik.

Yau, Y. (2011): Does comprehensive redevelopment change the housing price gradient? A case study in Mongkok, Hong Kong. Urbani izziv, 22(2), str. 22-35. DOI: 10.5379/urban-izziv-2011-22-02-003

Zhang, J., Kotze, N., in Yu, M. (2012) Living in a changing Chinese urban landscape: The Dalian case study. Urbani izziv, 23(2), str. 18-26.

DOI: 10.5379/urban-izziv-2012-23-02-002 